Gynecol. obstet. Invest. 1983;15:I-VI

\title{
Contents, Vol. 15, 1983
}

\section{No. 1 Original Paper}

Histological and Ultrastructural Pattern of Cervical Squamous Cell Carcinoma in a Young Woman

Kivinen, S.; Stenbäck, F 1

The Influence of Topical Vaginal Estrogen Application on the Lipids Metabolism

Blum, M.; Werchow, M.E.; Yeshurun, D 10

Urinary Mucopolysaccharide Excretion in Early Pregnancy

Gorodeski, I.G.; Wasserman, L.; Neri, A.; Bahari, CM 16

Human Placental Lactogen Serum Levels in Venous and Capillary Blood from Women in Late Pregnancy

Axelsson, O.; Malmström, H 19

Antibacterial Activity in Amniotic Fluid from West Virginia Women

Larsen, B.; Hurry, D.J.; Miro, R.E.; Charles, D 26

Regional Variations in Uterine Blood Flow in the Guinea Pig: Relationship to Pregnancy

Site Distribution

Garris, D.R.; Blankenship, L.T.; Whitehead, D.S 33

Cell-Mediated Immunocompetence of Children Exposed in utero to Short- or Long-Term Action of Glucocorticoids

Kauppila, A.; Hartikainen-Sorri, A.-L.; Koivisto, M.; Ryhänen, P 41

Concanavalin A Agglutinability and Immunoadherent Properties of Rat Blastocyst

Fein, A.; Toder, V.; Nebel, L 49

Publisher's Note 63

Book Review 64

No. 2 Original Paper

Amniotic Fluid Amylase Concentration: a Reliable Predictor of Fetal Maturity?

Feijen, H.W.H.; Renzo, G.C. di; Haan, J. de; Houx, P.C.W.; Nederstigt, J 65

Motor Nerve Conduction Velocity for Assessment of Gestational Age in Twins

Goeschen, K.; Pluta, M.; Rothe, J.; Saling, E 74

Relationship between Deciduoma Formation and Uterine Blood Flow in the Pseudopregnant Rat

Garris, D.R.; Fair, J.H.; Whitehead, D.S.; Muse, P.D

Relative Fatty Acid Composition of Serum Lecithin in the Normal Puerperium

Rosing, U.; Johnson, P.; Ölund, A.; Samsioe, G 93

IV Contents

The Role of Phospholipids in the Binding of Oxytocin to Its Receptors in Lactating Rabbit Mammary Gland

Warr, J.L.; Branda, L.A 103

Catamnestic Examinations Performed after the Utilization of Two Different Sterilization Techniques 
Riedel, H.-H.; Semm, K

Book Reviews 127

No. 3 Original Paper

Reproducibility of Simultaneous Urethrocystometry Measured with Electronic Microtransducers

Reyes, H.; Weil, A 129

Survival Data of Israeli Jewish Patients with Squamous Cell Carcinoma of the Cervix

Treated by Irradiation

Menczer, J.; Atlas, M.; Werner, A.; Chaitchik, S.; Herzberg, A.; Rath, P.; Brenner, H. . 141

Glycogen Metabolism of Normal Human Myometrium and Leiomyoma - Possible Hormonal Control

Milwidsky, A.; Gutman, A 147

Antithrombin III and Platelets during the Normal Menstrual Cycle and in Women Receiving

Oral Contraceptives Low in Oestrogen

Jespersen, J.; Ingeberg, S.; Bach, E 153

Establishment of a Method for Preservation of Human Cervical Mucus for in vitro Penetration

Tests

Baruch, A.L.; Yedwab, G.; David, M.P.; Homonnai, Z.T.; Paz, G.F163

Sialic Acid in Lymphocytes and Sera from Mothers and Their Newborns after Normal

Deliveries

Halbrecht, I.; Komlos, L.; Levinsky, H.; Goldman, J.; Allalouf, A 171

Gastric Aspirate Lecithin/Sphingomyelin Ratio and Neonatal Breathing Difficulties

Korvenranta, $\mathrm{H} \quad 177$

Inhibition of Puerperal Lactation by Metergoline: Interactions with Methylergobasine

Maleate

Scapin, F.; Calistri, D.; Tronconi, G.; Pellicciotta, G.; Bareggi, S.R.; Pontiroli, A.E. . . 185

Book Reviews 191

No. 4 Review

Ultrastructural Changes in Human Endometrium at Different Phases of the Menstrual Cycle and Their Functional Significance

Verma, V 193

Original Paper

Effect of Celioscopic Ovarian Resection in Patients with Polycystic Ovaries

Campo, S.; Garcea, N.; Caruso, A.; Siccardi, P 213

Fibrinolytic Activity in the Walls of Foot Veins in Women Using Combined Contraceptive Pills

Kjaeldgaard, A.; Larsson, B 223

Contents

$\mathrm{V}$

Bacteroidesfragilis, Streptococcus intermedius and Group B Streptococci in Ascending Infec tion of Pregnancy. An Animal Experimental Study

Evaldson, G.; Malmborg, A.-S.; Nord, C.E.; Östensson, K 230

Pattern of Glycosaminoglycan Distribution in Tissue and Blood Vessels of Human

Placenta

Wasserman, L.; Shlesinger, H.; Goldman, J.A.; Allalouf, D 242 
Antenatal Glucocorticoid Administration: Effects on Oxygen-Hemoglobin Affinity and Hemoglobin Levels in Experimental Hyaline Membrane Disease

Truog, W.E.; Kessler, D.L.; Murphy, J.; Standaert, T.A.; Woodrum, D.E.; Hodson,

W.A 251

Book Reviews 258

No. 5 Original Paper

Cytophotometric Determination of DNA in Minimal Invasive Cancer of the Cervix uteri

Herzog, R.E.; Ciprian, C 261

Sequential Study of Plasma Euglobulin Fibrinolytic Activity during the Normal Menstrual

Cycle and in Women on Oral Contraceptives Low in Estrogen

Jespersen, J 266

Oral Contraception with a Nonalkylated Estrogen Component. Effects on Lipid Metabolism

Samsioe, G; Skryten, A.; Silfverstolpe, G 275

Effects on Temperature on Arterial and Cutaneous p02 in the Rabbit

Silverman, F.; Young, B.K 283

Biochemical Changes in Human Cervical Connective Tissue after Local Application of

Prostaglandin E2

Uldbjerg, N.; Ekman, G; Malmström, A.; Ulmsten, U.; Wingerup, L 291

Heart Rate and Blood Pressure Response and Metabolic Changes in the Sheep Fetus following

Reduction of Uterine Blood Flow

Künzel, W.; Kastendieck, E.; Hohmann, M 300

Neurological Sequelae in High- and Low-Optimality Obstetrics

Huisjes, H.J.; Lok-Meijer, T.Y.; Touwen, B.C.L.; Olinga, A.A 318

Book Reviews 323

Announcement 299

No. 6 Original Paper

Reproductive Function following Advanced Ovulation Induced by Synthetic Luteinizing Hormone Releasing Hormone in Rats

Morishita, H.; Mitani, H.; Nakago, K.; Higuchi, K.; Mori, T325

Pregnancy Rate after Homologous Insemination of Pathological Ejaculate both with and without the Addition of Kallikrein

Maier, U,; Grünberger, W.; Binstorfer, E.; Lunglmayr, G 337

Prostaglandins E and F in Amniotic Fluid during Stretch-Induced Cervical Softening and Labor at Term

Manabe, Y.; Okazaki, T.; Takahashi, A 343

Synthesis of Thromboplastin (Factor III) in Mouse Placental Cells in vitro

Dalaker, K.; Kaplun, A.; Lyberg, T.; Prydz, H 351

VI

Contents

Current Investigations

Does Prolactin Influence First Trimester Abortion? A Preliminary Clinical Observation

Peer, E.; Peretz, B.A.; Paldi, E 362

The Predictive Value of the DHAS Loading Test in Pregnancies for Intrauterine Fetal

Growth Retardation

Keller, P.J.; Lysikiewicz, A.; Huch, R 365

Book Reviews 372 
Author Index 378

Subject Index 380 